\title{
Evaluating Accuracy and Precision in Morphologic Traits for Sexual Dimorphism in Malnutrition Human Skull: a Comparative Study
}

\author{
Evaluación de la Exactitud y Precisión en los Rasgos Morfológicos de \\ Dimorfismo Sexual en Cráneos Humanos Malnutridos: un Estudio Comparativo \\ *,**Iván Claudio Suazo Galdames; "Daniela Alejandra Zavando Matamala \& ** Ricardo Luiz Smith
}

SUAZO, G. I. C.; ZAVANDO, M. D. A \& SMITH, R. L. Evaluating accuracy and precision in morphologic traits for sexual dimorphism in malnutrition human skull: a comparative study. Int. J. Morphol., 26(4):877-881, 2008.

SUMMARY: One of the most important purposes of anthropological studies of human skeletons protocol is the determination of sex. Some skulls may be wrongly classified due to systemic conditions presented during the life of individuals who affected the muscle forces that act on bones, as is the case of severe malnutrition. The purpose of this study is to analyze the effect of severe malnutrition on morphological determinants of sexual dimorphism classically studied in the visual analysis of the skull. 163 human skulls were analized with sex, age and cause of death known, belonging to the collection of Universidad Federal de Sao Paulo (UNIFESP). We performed visual inspection of the skull and diagnosis of sex based on size and overall architecture of the skull, an aspect of the zygomatic bone, size and roughness of the mastoid process, ridges of the occipital bone and general appearance of the jaw. The skulls were classified into two groups according to whether severe malnutrition had described in his cause of death $(n=60)$ or had other cause of death ( $n=103)$. The results of the inspection were compared with the registry to determine the accuracy in diagnosis and sensitivity of the method for male and female in both groups analyzed. In the group with malnutrition the best indicator was the appearance of the zygomatic bone, with a $86.6 \%$ accuracy. In another group closely was found in the size of the mastoid (87.3\%). In both groups the highest values of sensitivity were for male (83.3-95.3\%). The sensitivity to female showed lower values in the group without malnutrition $(69.2-76.9 \%)$ than in the group withmalnutrition $(72.4-89.65 \%)$, these differences were statistically significant $(\mathrm{p}<0.05)$.

KEY WORDS: Sexual Dimorphism; Determination of sex; Severe malnutrition.

\section{INTRODUCTION}

The diagnosis of sex in bone remnants with varying conservation degrees is necessary in forensic practice and forensic anthropology. There have been numerous methods to make the determination of sex, they can be divided into two groups: morphological and molecular methods (Rösing et al., 2007).

The morphological methods used anthropometry and are supplemented, at present, with multivariate statistical models, especially discriminant analysis. The molecular methods are more accurate, however, require an infrastructure and technical expertise more complex, why are used when morphological indicators are not sufficient to determine the sex. Generally, in presence of skeletal elements in good condition, morphological indicators of sexual dimorphism allow a correct diagnosis in more than $95 \%$ of cases (Baughan \& Demirjian, 1978; Franklin et al., 2005, Kimmerle et al., 2008).
The determination of sex is more accurate in adults than in subadults owing to the effect of sex hormones, estrogen and progesterone on the development of morphological differences, which have their ultimate expression after puberty. The hormones, control the development and growth of bones; differences between the sexes are by different speeds and forces in the bone development. Female complete their development earlier than males, who changed his appearance dramatically at puberty. Therefore, biomorphological differences between the sexes, manifested most clearly in adult skeletons (Krenzer, 2006).

There is also socio-environmental influences (eg nutrition food, climate, pathologies, etc.), influencing the development and the appearance of bones (Park \& Nowosielski-Slepowron, 1983). There is evidence of major

\footnotetext{
* Departamento de Anatomía Normal, Universidad de Talca, Chile.

** Departamento de Morfología y Genética. Universidad Federal de Sao Paulo, Brasil.
} 
alterations on the rate and timing of growth in humans who suffered some form of malnutrition, particularly protein restriction (Golden, 1994).

The craniofacial skeleton is a portion of the body, that is critically affected by malnutrition; have been reported alterations in the growth trajectories of the skull in rats subjected to severe malnutrition (Miller \& German, 1999). In another study, were examined the effect of malnutrition in adult rats on cranial sexual dimorphism indicators, with a decrease of $23 \%$ in the group of rats undernourished (Dahinten \& Pucciarelli, 1986). It has been reported that alterations in the shape of the cranial skeleton associated with severe malnutrition can be transgenerational, affecting up to F3 (Cesani et al., 2003).

Furthermore, the shape of bone is a logical consequence of their role; bones are shaped according to their specific biomechanical needs (Krenzer). The bone and muscle determines elevations with an insertion muscle stronger cortical thickness grows proportionally and there is evidence that the slowdown in action predisposes the muscle atrophy in the bone tissue, with remodelation in terms of thickness and substance loss, particularly at compact bone (Mitch, 2000, Beardall \& Johnston, 1983).

Considering the influence that severe malnutrition has in the general organization of the skull and on the development of muscle forces that modeling the skull and determine the formation of ridges and elevations of great importance for the diagnosis of sex in human skulls. The purpose of this study is determine the accuracy and confiability of the morphological determinants classically studied in the visual analysis of the skull over two samples, one with severe malnutrition at death and one with other cause of death without malnutrition.

\section{MATERIAL AND METHOD}

We analyzed 163 human skulls belonging to the collection of UNIFESP. All skulls should correspond to adults skulls whose conservation status allowed to observe the parameters to analyze and should have a complete record of sex, race, age and cause of death. We excluded from this study those skulls with trauma, malformations or evident anatomical variations evidence. Its performed a blind qualitative analysis of five sexual dimorphism morphological indicators, according to the classic description (Krogman \& Iscan, 1986; Rogers, 2005). This analysis was performed by an observer in the area that remained under masking of records throughout the study and used a record collection created for diagnosis of sex by visual examination of human skulls.

The indicators studied were chosen because of the role played by the robustness of muscle insertions and strength to develop the muscles inserts in different processes in the development of the morphological differences associated with sex. The working hypothesis says that the severe malnutrition, as a cause of death, affects the accuracy of morphological parameters used for diagnosis of sex in cranial visual examination.

The elected indicators were:

- Size and overall architecture of the skull: the skull of male in general is more voluminous, heavy, cortical thicker and processes and ridges more marked than female.

- Zygomatic bone aspect: male in this bone-show robust, with development of the marginal tuber in the posterior edge of the frontal process and ridges especially at its lower edge. In female is thinner and smooth, in the areas of articulation with the frontal and zygomatic bone is more thinner.

- Size and ridges of mastoides process: the mastoid process develops heavily on male, both in size, robustness, as in the ridges for insertion muscle, these features are less marked in female.

- Roughness of the occipital bone: in the occipital bone in male exist a remarkable development of superior and inferior nuchal lines, as well as the external occipital protuberance, occipital crest and the insertion ruggedness, where inserting semispinosus muscle of the head. In female these features are less marked.

- Appearance of the jaw: the jaw of male is robust, presents marked ridges in the area of insertion of the masseter and medial pterigoid muscles, may file gonial eversion and a flexure in the posterior edge of the mandibular ramus at the height of occlusal plane and mandibular heads more voluminous. The females jaw is more smooth and graceful, lacks eversion and flexure, the mandibula head is smaller.

Later in order to analyze the effect of severe malnutrition has on the accuracy and sensitivity of the morphological indicators described in the skulls were classified into two groups: a) Group with malnutrition in their cause of death, consisting of 60 skulls, 31 male and 29 female, between 18 and 70 years old, with an average age of 35.5 years (SD 12.814). b) Group with a different cause of death and not related to severe malnutrition, this group consisted in 103 skulls, 64 male and 39 female, between 18 and 89 years old, with an average age of 46.11 years (SD 15.75). 
The data were analyzed using a contingency table for two by two for each indicator and determined the accuracy and sensitivity for male and female. By the remediation method a random sample of 40 skeletons intraobserver error were found.

\section{RESULTS}

In the precision test, the sample $(n=40)$ was measured again revealed some discrepancies between the first and second measurement, producing an intraobserver error $5.04 \%$, the highest error values were found in the size and overall architecture of the skull and in the size and roughness of the mastoid process, however all values were considered acceptable because they were below $10 \%$ intraobserver error. In Table I is a detail of the intraobserver error for each traits.

Once that precision was established, was determined the accuracy and sensitivity for each one of the 5 indicators analysed.

In the group with severe malnutrition, the indicator more accurately to determine the sex was the aspect of the zygomatic bone, with a $86.6 \%$ of individuals correctly classified, for male the best indicators were the size and overall architecture of skull and the size and ridges of the mastoid process, both with a $87 \%$ hit. For female in this group the best indicator was the aspect of the zygomatic bone with a $89.65 \%$.
In the group without malnutrition in their cause of death the best indicator of dimorphism was the size and roughness of the mastoid process, with a $87.3 \%$, this indicator also increased sensitivity to classify correctly male, $95.3 \%$. Female from this group had the lowest sensitivity for the diagnosis of sex in all indicators studied, with values of between $69.2-76.9 \%$ of individuals correctly classified as in another group, the best indicator was the appearance of zygomatic bone with a $76.9 \%$.

Table II shows the detail of the values of sex sensitivity and accuracy in each of the analysed traits.

The sensitivity average for male sensitivity without severe malnutrition in their cause of death was $90.99 \%$, while for the group with malnutrition, it was $85.37 \%$, differences that were significant at $\mathrm{p}<0.05$. Female without severe malnutrition, sensitivity average was $73.12 \%$, while for the group with severe malnutrition as the cause of death was $80.64 \%$, differences that were significant at $\mathrm{p}<0.01$.

Performing a combined ranking of accuracy and precision of the 5 analyzed indicators in two groups, it appears that the best indicators in subjects without severe malnutrition in their cause of death was ridges and occipital bone size and roughness of the mastoid process, while the group with severe malnutrition in their cause of death was the best indicator aspect of the zygomatic bone. Detailed results of the combined ranking of accuracy and precision for the 5 analyzed indicators can be seen in Table III.

Table I. It is a breakdown of values intraobserver error for each one traits.

\begin{tabular}{lccccc}
\hline & \multicolumn{2}{c}{ Severe malnutrition } & \multicolumn{2}{c}{ Other cause of death } & Total \\
\cline { 2 - 6 } Trait & $\mathrm{n}$ & Error $\%$ & $\mathrm{n}$ & Error \% & Trait error \% \\
\hline Size and overall architecture of the skull & 20 & 8 & 20 & 7.2 & 7.6 \\
Zygomatic bone aspect & 20 & 5.7 & 20 & 5.6 & 5.65 \\
Size and ridges of mastoides process & 20 & 6.2 & 20 & 4.4 & 5.3 \\
Roughness of the occipital bone & 20 & 2 & 20 & 3.4 & 2.7 \\
Appearance of the jaw & 20 & 4.1 & 20 & 3.8 & 3.95 \\
\hline
\end{tabular}

Table II. Details of the accuracy and sensitivity values to gender in 5 morphological indicators analysis.

\begin{tabular}{llccccccc}
\hline & \multicolumn{4}{c}{ Severe malnutrition } & \multicolumn{3}{c}{ Other cause of death } \\
\cline { 2 - 9 } Trait & $\mathrm{n}$ & Accuracy & $\begin{array}{l}\text { Male } \\
\text { sensitivity }\end{array}$ & $\begin{array}{l}\text { Female } \\
\text { sensitivity }\end{array}$ & $\mathrm{n}$ & $\begin{array}{l}\text { Accuracy } \\
\text { Male } \\
\text { sensitivity }\end{array}$ & $\begin{array}{l}\text { Female } \\
\text { sensitivity }\end{array}$ \\
\hline Size and overall architecture of the skull & 60 & 85 & 87 & 82.7 & 103 & 80.5 & 85.9 & 71.7 \\
Zygomatic bone aspect & 60 & 86.6 & 83.87 & 89.65 & 103 & 84.46 & 89 & 76.9 \\
Size and ridges of mastoides process & 60 & 83.3 & 87 & 79.3 & 103 & 87.3 & 95.3 & 74.3 \\
Roughness of the occipital bone & 60 & 78.3 & 83.3 & 72.4 & 103 & 84.4 & 93.75 & 69.2 \\
Appearance of the jaw & 52 & 82.6 & 85.7 & 79.16 & 90 & 84.4 & 91 & 73.5 \\
\hline
\end{tabular}


Table III. Comparing results of ranking accuracy and intraobserver error and combined ranking among severe malnutrition and other causes of death groups.

\begin{tabular}{|c|c|c|c|c|c|c|c|c|c|c|c|c|c|c|}
\hline \multirow[b]{2}{*}{ Trait } & \multicolumn{7}{|c|}{ Severe malnutrition } & \multicolumn{7}{|c|}{ Other cause of death } \\
\hline & $\mathrm{n}$ & Accuracy & $\begin{array}{l}\text { Rank } \\
\text { A }\end{array}$ & $\begin{array}{l}\text { Error } \\
\%\end{array}$ & $\begin{array}{l}\text { Rank } \\
\text { E }\end{array}$ & $\begin{array}{l}\text { Total } \\
\text { A+E }\end{array}$ & $\begin{array}{l}\text { Combined } \\
\text { Rank }\end{array}$ & $\mathrm{n}$ & Accuracy & $\begin{array}{l}\text { Rank } \\
\text { A }\end{array}$ & $\begin{array}{l}\text { Error } \\
\%\end{array}$ & $\begin{array}{l}\text { Rank } \\
\text { E }\end{array}$ & $\begin{array}{l}\text { Total } \\
\text { A+E }\end{array}$ & $\begin{array}{l}\text { Combined } \\
\text { Rank }\end{array}$ \\
\hline $\begin{array}{l}\text { Size and overall } \\
\text { architecture of the skull }\end{array}$ & 60 & 85 & 2 & & 5 & 7 & 3 & 103 & 80.5 & 4 & 7.2 & 5 & 9 & 4 \\
\hline Zygomatic bone aspect & 60 & 86.6 & 1 & 5.7 & 3 & 4 & 1 & 103 & 84.46 & 2 & 5.6 & 4 & 6 & 3 \\
\hline $\begin{array}{l}\text { Size and ridges of } \\
\text { mastoides process }\end{array}$ & 60 & 83.3 & 3 & 6.2 & 4 & 7 & 3 & 103 & 87.3 & 1 & 4.4 & 3 & 4 & 1 \\
\hline $\begin{array}{l}\text { Roughness of the } \\
\text { occipital bone }\end{array}$ & 60 & 78.3 & 5 & 2 & 1 & 6 & 2 & 103 & 84.4 & 3 & 3.4 & 1 & 4 & 1 \\
\hline Appearance of the jaw & 52 & 82.6 & 4 & 4.1 & 2 & 6 & 2 & 90 & 84.4 & 3 & 3.8 & 2 & 5 & 2 \\
\hline
\end{tabular}

\section{DISCUSSION}

The sex determination is an important part of anthropological analysis of cranial skeletons. There is a lot of factors that can alter the morphological traits of sexual dimorphism.

The present study analyzed the effect of severe malnutrition on a number of morphological indicators of sexual dimorphism. The results showed that severe malnutrition decreased accuracy for the diagnosis of male, this may be because the morphological indicators analysis, especially the aspect of the zygomatic bone, size and roughness of the mastoid process and ridges of the occipital bone are very sensitive to decreased muscle strength in the severe malnutrition, so in this visual examination group these traits tended to underestimate the males.

By contrast, females in the group with severe malnutrition in the cause of death, presented greater accuracy values, apparently, the decline in effect modeler muscle activity in this group determined that the traits observed accentuate their feminine characteristics to the visual examination. These results are within a context-specific population, which is characterized by a high incidence of severe malnutrition (Waitzberg et al., 2001; Batista Filho \& Rissin, 2003, Castro et al., 2004; Conde \& Monteiro, 2006); this background should be considered when making the anthropological examination of the skull and may partly explain mistakes in the classification of certain populations of Central Africa and South America.

Finally we must note that one of the limitations of this study is that basa in existing records, which have been made without a preexistent protocol. It is interesting that the study centers that receive skeletons possess registration protocols that give as much information and not be limited to sex, age and race.

SUAZO, G. I. C.; ZAVANDO, M. D. A \& SMITH, R. L. Evaluación de la exactitud y precisión en los rasgos morfológicos de dimorfismo sexual en cráneos humanos malnutridos: Un estudio comparativo. Int. J. Morphol., 26(4):877-881, 2008.

RESUMEN: Uno de los propósitos más importantes del protocolo antropológico de estudios de osamentas humanas, es la determinación del sexo. Algunos cráneos pueden ser clasificados erróneamente debido a condiciones sistémicas presentadas durante la vida de individuos que hayan afectado a las fuerzas musculares que actúan sobre el hueso, como es el caso de la desnutrición severa. El propósito de este estudio fue determinar la exactitud y confiabilidad, sobre los parámetros morfológicos determinantes de dimorfismo sexual, clásicamente estudiados en el análisis visual del cráneo, para los dos grupos que componen la muestra, uno con desnutrición acompañando el momento del deceso y otro con causa de muerte sin ese factor acompañante. Se utilizaron 163 cráneos humanos de sexo, edad y causa de muerte conocido, pertenecientes a la colección de la UNIFESP. Se realizaron la inspección visual del cráneo y el diagnóstico de sexo en base a: tamaño y arquitectura general del cráneo, aspecto del hueso cigomático, tamaño y rugosidades del proceso mastoides, rugosidades del hueso occipital y aspecto general de la mandíbula. Los cráneos fueron clasificados en dos grupos, de acuerdo a si presentaron desnutrición severa descrita en su causa de muerte $(n=60)$ o presentaban otra causa de muerte $(n=103)$. Los resultados de la inspección se compararon con la del registro para determinar la exactitud en el diagnóstico y la sensibilidad del método para hombres y mujeres, en los dos grupos analizados. En el grupo con desnutrición, el mejor indicador resultó el aspecto del hueso cigomático, con un 86,6\% de exactitud. En el otro grupo, la mayor exactitud se encontró en el tamaño del proceso mastoides (87,3\%). En ambos grupos, los mayores valores de sensibilidad fueron para hombres $(83,3-95,3 \%)$. La sensibilidad para mujeres presentó menores valores en el grupo sin desnutrición (69,2-76,9\%) que en el grupo con desnutrición $(72,4-89,65 \%)$, estas diferencias resultaron estadísticamente significativas $(\mathrm{p}<0,05)$.

PALABRAS CLAVE: Dimorfismo sexual; Determinación del sexo; Desnutrición severa. 


\section{REFERENCES}

Baughan, B. \& Demirjian, A. Sexual dimorphism in the growth of the cranium. Am. J. Phys. Anthropol., 49:38390, 1978.

Batista Filho, M. \& Rissin, A. Nutritional transition in Brazil: geographic and temporal trends. Cad. Saude Publica, 19(1):S181-91, 2003.

Beardall, C. H. \& Johnston, I. A. Muscle atrophy during starvation in a marine teleost. Eur. J. Cell Biol., 29:20917, 1983.

Castro, T. G.; Campos, F. M.; Priore, S. E.; Coelho, F. M. G.; Campos, M. T. F. S.; Franceschini, S. C. C. \& Rangel, A. A. Saúde e nutrição de crianças de 0 a 60 meses de um assentamento de reforma agrária, Vale do Rio Doce, MG, Brasil. Rev. Nutr., 17(2):167-76, 2004.

Cesani, M. F.; Orden, B.; Zucchi, M.; Mune, M. C.; Oyhenart, E. E. \& Pucciarelli, H. M. Effect of undernutrition on the cranial growth of the rat. An intergenerational study. Cells Tissues Organs, 174:129-35, 2003.

Conde, W. L. \& Monteiro, C. A. Body mass index cutoff points for evaluation of nutritional status in Brazilian children and adolescents. J. Pediatr. (Rio J.), 82(4):26672, 2006.

Dahinten, S. L. \& Pucciarelli, H. M. Variations in sexual dimorphism in the skulls of rats subjected to malnutrition, castration, and treatment with gonadal hormones. Am. J. Phys. Anthropol., 71:63-7, 1986.

Franklin, D.; Freedman, L. \& Milne, N. Sexual dimorphism and discriminant function sexing in indigenous South African crania. Homo, 55:213-28, 2005.

Golden, M. H. Is complete catch-up possible for stunted malnourished children? Eur. J. Clin. Nutr., 48(1):S5870, 1994.

Kimmerle, E. H.; Ross, A. \& Slice, D. Sexual dimorphism in america: geometric morphometric analysis of the craniofacial region. J. Forensic Sci., 53:54-7, 2008.

Krenzer, U. Compendio de Métodos Antropológico Forenses. Guatemala, D. E. D. Guatemala, 2006.

Krogman, W. E. \& Iscan, M. Y. The Human Skeleton in Forensic Medicine. $2^{\text {nd }}$ ed. Springfield, Thomas, 1986.
Miller, J. P. \& German, R. Z. Protein malnutrition affects the growth trajectories of the craniofacial skeleton in rats. J. Nutr., 129:2061-9, 1999.

Mitch, W. E. Mechanisms accelerating muscle atrophy in catabolic diseases. Trans. Am. Clin. Climatol. Assoc., 111:258-69; discussion 269-70, 2000.

Park, A. W. \& Nowosielski-Slepowron, B. J. Postnatal skull growth of the rat relative to environmental variance. Acta Morphol. Neerl. Scand., 21:141-63, 1983.

Rogers, T. L. Determining the sex of human remains through cranial morphology. J. Forensic Sci., 50:493-500, 2005.

Rösing, F. W.; Graw, M.; Marré, B.; Ritz-Timme, S.; Rothschild, M. A.; Rötzscher, K.; Schmeling, A.; Schröder, I. \& Geserick, G. Recommendations for the forensic diagnosis of sex and age from skeletons. Homo, 58(1):75-89, 2007.

Waitzberg, D. L.; Caiaffa, W. T. \& Correia, M. I. Hospital malnutrition: the Brazilian national survey (IBRANUTRI): a study of 4000 patients. Nutrition, 17(7-8):573-80, 2001.

Correspondence to:

Prof. Dr. Iván Suazo Galdames

Departamento de Anatomia Normal

Universidad de Talca

Avenida Lircay s/n Oficina $\mathrm{N}^{\circ} 104$

Talca - CHILE

Email: isuazo@utalca.cl

Received: 14-09-2008

Accepted: 12-10-2008 
